Merja Almokari \& Pekka Isotalus (toim.) 2009.

\title{
Akateeminen puheviestintä. Kuinka opettaa puheviestintää yliopisto-opiskelijoille
} Helsinki: Finn Lectura. (169 s.)

Puheviestinnän lehtori Merja Almonkarin ja professori Pekka Isotaluksen toimittama kirja koostuu kahdeksasta artikkelista, joissa kokeneet puheviestinnän opettajat valottavat puheviestinnän opettamisen eri osa-alueita tekemiinsä tutkimuksiin perustuen. Kirjassa tarkastellaan, miten puheviestintäosaamista opetetaan ja olisi hyvä opettaa yliopisto-opiskelijoille. Esipuheessa tuodaan esiin, että kirja on suunnattu oppikirjaksi.

Kysymyksenasetteluna ensimmäinen Gerlanderin, Hyvärisen, Almonkarin ja Isotaluksen artikkeli Mitä ja miten puheviestinnän opintojaksoilla opetetaan kertoo, millaista puheviestinnän opetus on ollut Suomen yliopistoissa vuonna 2006. Sähköisen e-lomakekyselyn tulokset osoittavat runsasta vaihtelevuutta ja epäyhtenäisyyttä puheviestinnän opetuksessa, ja artikkeli herättää toiveen valtakunnallisesta yhteistyöstä. Vastauksena alun kysymykseen kirjan viimeinen artikkeli puolestaan esittelee valtakunnallisen LAAPU-hankkeen (laatua puheviestinnän opetukseen) suosittelemat yliopistotutkintojen kieli- ja viestintäopintoihin kuuluvan puheviestinnän opetuksen tavoitteet ja ydinsisällöt. Suositusten lähtökohtana on se, että kandidaatin tutkintoon kuuluvaa puheviestinnän opetusta annetaan yliopistossa, joka on oppimisen ja opiskelun sekä tieteellisen tiedon käsittelyn ja tutkimuksen tekemisen konteksti.

Opetukseen liittyviä tavoitteita nostetaan esille myös työelämän näkökulmasta. Koivuoja ja Isotalus esittelevät Tampereen yliopistosta valmistuneiden näkemyksiä työelämän puheviestinnästä ja saamastaan puheviestinnän opetuksesta. Artikkeli tuo mukavasti esille muun muassa humanististen ja yhteiskuntatieteellisten alojen tarpeita, jotka ovat enemmän yleisiä kuin alakohtaisia ja joiden perusteella opetuksen tulisi palvella työelämän asiantuntijatehtävissä toimimista. Artikkelin mukaan opiskelijat toivovat, että puheviestinnän opetus olisi monipuolista ja sisältäisi erityisesti esiintymistaitojen ja työelämän ryhmäviestintätaitojen harjoittelua.

Kaikki edellä mainitut artikkelit nostavat esille tarpeen ja antavat suuntaviivoja sen pohtimiselle, kuinka opettaa puheviestintää yliopistossa. Näitä aiheita pohditaan kuitenkin melko suppeasti teoksen ilmoitettuun tavoitteeseen nähden: akateemisen puheviestinnän oppikirjassa soisi olevan runsaammin opetuksen sisältöihin ja menetelmiin liittyvää keskustelua ainakin tieteellisen vuorovaikutuksen näkökulmasta. Myöskään ryhmäviestintää ei ole teoksessa käsitelty, 
vaikka esipuheessa mainitaan yhteistyö moniammatillisissa ryhmissä, neuvotteleminen sekä kokousten ja palaverien vetäminen.

Tieteenalakohtaisten, spesifeille aloille valmistavien opintojen näkökulmasta on kirjoitettu kaksi artikkelia. Näistä ensimmäinen on Jonna Koposen artikkeli Vuorovaikutusosaamisen opettaminen lääketieteen opiskelijoille. Se esittelee Kuopion yliopiston opetuskokeilun sekä opiskelijoiden näkemyksiä aiheesta. Marja-Leena Hyvärisen artikkeli Farmaseuttiopiskelijoiden ammatillinen puheviestinnän oppiminen ja opettaminen kuvaa farmasian opiskelijoille suunnatun Vuorovaikutustaidot ja asiakasneuvonta apteekissa -opintojakson kehittämistyötä Kuopion yliopistossa. Artikkelissa tarkastellaan, miten opetus on nivottu työelämän harjoitteluun ja millaisia oppimistuloksia kehityksen seurauksena on saavutettu.

Näiden artikkelien paras anti on tarkoissa oppimisprosessien ja opetusmenetelmien kuvauksissa. Koposen artikkelin tulokset ja niistä nousevat perustelut kokemuksellisten oppimismenetelmien toimivuudesta (erityisesti tässä tapauksessa potilashaastatteluharjoitukset harrastajanäyttelijöiden kanssa) ovat innostavaa luettavaa niille, jotka haluavat tarkastella spesifejä vuorovaikutustilanteita simuloidusti, oikean elämän kaltaisesti, eivätkä pelkää laajentaa menetelmällistä osaamistaan draaman puolelle. Artikkelista saatu menetelmätietous soveltuu monenlaisten, erityisesti interpersonaalisten vuorovaikutustilanteiden tarkasteluun. Hyvärisen artikkelista jää erityisesti mieleen farmasian opintoihin kuuluvan puheviestinnän opetuksen alakohtaisuuden ja työelämäsuuntautuneisuuden vaatimus.

Kokonaisuudesta hieman irralliseksi jäävät Merja Almonkarin artikkeli Esiintymisjännitys opetuksen aiheena ja Anne Alanteen artikkeli Ä̈̈nenkäytön opettaminen yliopisto-opiskelijoille. Teemat ovat tärkeitä, mutta artikkelit olisivat toimineet paremmin, jos niiden seurana olisi ollut myös muita selkeästi puheviestinnän ilmiöitä ja opetuksen sisältöjä käsitteleviä artikkeleja. Almonkarin artikkelia oli miellyttävä lukea. Se on kirjoitettu opetuksen näkökulmasta ja siinä puhutellaan opettajaa; on nostettu esille keskeistä opetuksen sisällöistä ja opetustavasta. Anne Alanteen artikkeli kuvaa äänenkäytön oppimistilannetta vuorovaikutustilanteena, jossa saa ilmaista tunteita ja jossa erilaiset käsityksen äänestä, äänetuotosta, äänenkäytön harjoituksista ja äänenkäytön kehittämisestä kohtaavat. Artikkelista hyötyvät eniten ne, joilla on äänenkäytön opetukseen liittyvää konkreettista osaamista jo ennestään.

Isotaluksen ja Mäen pohdinta Tiedon rooli puheviestinnän oppimisessa: tapaustutkimus opiskelijoiden kokemuksesta ei tarjoa erityisemmin uutta näkökulmaa. Päätutkimuskohteena on luento-opetuksen hyödyllisyys. Löyhästi kiteytettynä johtopäätös on se, että tulosten perusteella ei voi pitää tavoiteltavana, että korvataan harjoitusopetus luennoilla, mutta parhaimmillaan luento voi olla stimuloiva ja oppimista edistävä. Artikkelilta jäin kaipaamaan selkeämpää puheviestintätiedon jäsennystä. Esimerkiksi sitä ei juurikaan avattu, miten 
ja millaista tietoa luennoilla opetettiin ja millaisia asioita ja miten opiskelijat kokivat oppivansa. Artikkeli kuitenkin muistutteli siitä, että puheviestintäosaamisen ulottuvuuksien painotuksia on tarpeen kirkastaa.

Tarja Tantun kirjoitus Arvostusta osaamiselle: aiemmin hankitun puheviestintäosaamisen tunnistaminen ja tunnustaminen portfolio- ja näyttöpäivätyöskentelyssä esittelee Joensuun yliopiston AHOT-menettelyä.

Joensuun malli on kokonaisvaltainen oppimisprosessi ja opiskelijapalautteiden mukaan toimiva kokonaisuus, joka antaa eittämättä suuntaviivoja AHOTmenettelyjen suunnittelulle. Joensuun malli vaikuttaa kuitenkin laajuutensa puolesta enemmänkin vaihtoehtoiselta suoritustavalta kuin aiemmin hankitun osaamisen näytöltä.

Akateeminen puheviestintä -teosta on helpointa lukea artikkeli kerrallaan, eikä pelkkä oppikirjanimike erota sitä puheviestinnän aiemmista tutkimusartikkelikokoelmista. Oppikirjan käsite on ilmeisen venyvä, mutta kirjaa olisi voinut myös muokata sellaiseen suuntaan, että kirjoittajien ääni olisi yhtenäisempi. Artikkelien aiheet ovat mielenkiintoisia, mutta kokonaisuus jää hajanaiseksi. Joitakin kiinnostavia ajatuskulkuja tosin kehitellään artikkeleiden välillä, mutta artikkelien kirjoitustyylissä jäi kaipaamaan enemmän lukijaa ohjaavaa otetta yhteenvetoja ja opettamisen kannalta olennaisen esille nostamista.

Osittain artikkelikokoelman luonteesta seuraa, että aivan aloittelevan opettajan käsikirjaksi teoksesta ei välttämättä ole. On tunnettava puheviestinnän opetuskenttää, jotta tiedon joukosta osaa poimia tuen omaan opettamiseensa. Kirja antaa kuitenkin hyvän kokonaiskuvan siitä, mitä puheviestinnän yliopistoopetuksen kehittämisen eteen on tehty niin eri puolilla Suomea yksittäisten opettajien voimin kuin valtakunnallisen yhteistyönkin tuloksena. Kirjasta välittyy myös se, miten moneen tarpeeseen puheviestinnän opetuksen on vastattava - ja miten moneen tarpeeseen se jo vastaa. Artikkelit kertovat tarinaa erittäin motivoituneista, kokeneista ja eri aloilla pätevöityneistä opettajista. Kirja myös esittelee ja herättelee herkullisia kysymyksenasetteluja, joten ajatuksia ja oivalluksia se taatusti herättää.

\section{Tuuli Nilsson}

